\title{
The measure of migratory flows between France and other countries; what if we also spoke of emigration?
}

La mesure des flux migratoires entre la France et l'étranger: et si on parlait (aussi) d'émigration?

La medición de los flujos migratorios entre Francia y otros países. ¿Y si hablamos (también) de emigración?

\section{Franck Temporal and Chantal Brutel}

\section{(2) OpenEdition}

Electronic version

URL: https://journals.openedition.org/remi/12090

DOI: $10.4000 /$ remi. 12090

ISSN: $1777-5418$

This article is a translation of:

La mesure des flux migratoires entre la France et l'étranger : et si on parlait (aussi) d'émigration ? -

URL : https://journals.openedition.org/remi/8270 [fr]

Other translation(s):

Roma and Gypsies in the Mediterranean: Circulating Categories, Maintaining Boundaries - URL : https://journals.openedition.org/remi/8478 [en]

The Arab Spring: A Revolution for Egyptian Emigration? - URL : https://journals.openedition.org/remi/ 8481 [en]

"The cinema needs the individual, and migrants need the cinema to re-emerge as an individual." Interview with Andrea Segre - URL : https://journals.openedition.org/remi/8595 [en] Mapping the Migratory Movements - URL : https://journals.openedition.org/remi/8803 [en] Immigrant Youth in Canadian Postsecondary Education: Pathway Morphologies in the Province of Quebec - URL : https://journals.openedition.org/remi/12100 [en]

Publisher

Université de Poitiers

Printed version

Date of publication: 1 December 2016

ISBN: 979-10-90426-29-0

ISSN: 0765-0752

\section{Electronic reference}

Franck Temporal and Chantal Brutel, "The measure of migratory flows between France and other countries; what if we also spoke of emigration?", Revue européenne des migrations internationales [Online], vol. 32 - $n^{\circ} 3$ et 4 | 2016, Online since 01 December 2018, connection on 14 April 2022. URL: http://journals.openedition.org/remi/12090 ; DOI: https://doi.org/10.4000/remi.12090 
This text was automatically generated on 14 April 2022.

(C) Université de Poitiers 


\title{
The measure of migratory flows between France and other countries; what if we also spoke of emigration?
}

\author{
La mesure des flux migratoires entre la France et l'étranger: et si on parlait \\ (aussi) d'émigration? \\ La medición de los flujos migratorios entre Francia y otros países. ¿Y si hablamos \\ (también) de emigración?
}

Franck Temporal and Chantal Brutel

Measuring migratory flows has always been a complex and sensitive subject. Over the last few decades, knowledge of immigration and above all emigration flows has remained incomplete. The demographer Xavier Thierry noted that according to the European Statistical Office (Eurostat), these flows were unknown for seven of the twenty seven member States of the European Union in 2005, including France (Thierry, 2008b). The figures vary greatly according to country, making international comparisons difficult. These difficulties have long been linked to the many different sources used to measure international movements, just as the definition of migrant varies from one country to another, especially when taking into account the length of stay. Regarding the latter, the Organisation of Economic Cooperation and Development (OECD) and the United Nations have formulated recommendations aimed at improving the statistics produced by countries (UN, 1998). In particular, they established a definition of international migrant based on a change of usual residence in one country to another for a duration lasting for at least twelve month, independently of the criterion of nationality or reason for migration. These recommendations were then incorporated in regulation (EC) no. 862/2007 of the Parliament and the Council of 11 July 2007 relating to community statistics on migration and international protection ${ }^{1}$, abrogating regulation (EEC) no. $311 / 76$ of the Council on the establishment of the status of foreign workers. These new common rules oblige the Member States to provide 
community statistics on immigration and emigration in terms of destination and origin to and from the territories of the Member States to another Member State or a third country. The aim therefore is to measure international and national migrations of the citizens from a member country or of those from a country outside Europe. This information must be completed with statistics on international protection (demands for asylum), on clandestine entries and stays, on residence permits and on returns. With this in view, the European Council and Parliament identified several sources of usable data such as records of administrative and legal proceedings, records of populations regarding administrative proceedings, censuses, sample surveys and any other appropriate source.

Given this context, this article presents the method of estimating migratory flows between France and abroad adopted by the Institut National de la Statistique et des Etudes Economiques (INSEE) and several of the main results of the period 2006-2014. It shows the way in which this new method of estimating migratory flows provides a global view of migrations, as it allows quantifying departures from French territory for the first time. Indeed, emigration has not only long remained absent from statistics, but also from public and political debates on the issue of migration.

We first deal with the question of how could the imperfection of measurement tools linked with the French historic context have led to both limiting attention only to the issues of immigration and to the movements of foreigners? We then describe the method of estimating migratory flows between France and other countries developed by the INSEE at the end of 2015. Lastly, we discuss several results obtained in recent years: although France remains a country of immigration, it is also one of emigration.

\section{Measuring migratory flows, a truncated equation?}

\section{Incomplete statistics}

Immigration flows in the different countries of the world are usually estimated on the basis of various administrative data (residence permits, work permits and population registers). The estimation of emigration flows is much rarer, as few countries record departures, mainly those which have population registers. For many years, France failed to comply with international and European recommendations on the measurement of migratory flows with other countries. Indeed, it supplied Eurostat with an estimation of foreign immigration from third countries and Member States of the European Union, but no information on flows of departures of foreigners (migrants returning to their home country and departures to other countries), or on the relative movements of French nationals (departures and returns of French nationals from abroad). This situation resulted from the poor quality of administrative sources, often partial regarding entries into France, and above all from the lack of estimations on departures.

5 Contrary to countries that keep population registers, emigration flows do not give rise to statistical records and there is no exhaustive database on the stocks of French nationals who have settled abroad. Nonetheless, several sources exist. The world register of French citizens settled in a foreign country is managed by the Ministry of Foreign Affairs. French citizens are advised to enrol on this register as it permits simplifying their administrative procedures abroad; however it is optional. This 
consular source nonetheless remains incomplete (Brutel, 2015a). The OECD manages a database that gathers censuses from the thirty four member countries, making it possible to estimate the number of French citizens living abroad, though once again, this source does not include certain receiving countries (Brutel, 2015a). Several other paths, such as carrying out a specific survey to estimate expatriations indirectly have been studied (Thierry, 2008b). Others have made mention of taking administrative sources into account, notably health insurance, to estimate migratory flows from France to other countries (Riandey, 2007).

Statistics are more numerous regarding arrivals in France of French citizens born abroad, returns of nationals who have emigrated previously, or arrivals of foreigners from a member State of the European Union or outside it, but they have shortcomings. For several years, the data sent by France to Eurostat only covered entries of foreigners on the basis of administrative sources such as data from the National Agency for the Reception of Foreigners and Migrations (ANAEM), applications for asylum received by the French Office for Protection of Refugees and the Stateless (OFPRA) and the file for applications for residence permits managed by the Prefectures (Thierry, 2008b). These statistics do not take into account foreigners without residence permits, students, seasonal and temporary workers (Cornuau and Dunezat, 2008). In parallel, The National Institute for Demographic Studies (INED) performs its own estimations of migratory flows, mainly on the basis of data called AGDREF, from the management of files of foreign nationals in France. This estimation, deemed in compliance with international recommendations, provides an estimation of the flows of entries of foreigners from outside Europe, and is completed by an estimation of Community residents not obliged to apply for a residence permit. However, as stated by Mazuy et al (2011) in their INED article on the demographic situation, this estimation had to be shelved temporarily and then revised following a change in the law on residence permits in France in June 2009. In brief, this reform led to waiving the requirement for certain nationals of countries outside Europe holding long-stay permits equivalent to residence permits ("VLS/TS") to apply for a residence permit at a Prefecture during their first year of residency, thereby affecting the precision of flow estimations based on residence permit files. Since this reform, the INED has produced a new estimation of migratory flows based on administrative information on residence permits issued to foreigners residing in France (Mazuy et al., 2015; Albis and Boubtane, 2015). This source of data covers only foreign immigration, thus movements of French nationals are not taken into account, nor are foreign nationals without residence permits. In other words, foreign nationals not obliged to apply for residence permits, which is the case for citizens of EU countries, while foreigners residing illegally in France are not accounted for. In addition, due to the administrative nature of the files used, the number of entries thus estimated corresponds to entries in a legal category and not to a genuine entry in the country. The date of the application for a residence permit can differ from that of the person's arrival in France. The estimation of departures is even less precise, as the expiry of a permit does not necessarily signal a departure from the territory. More than a demographic event, the measure focuses in this case on administrative events. Despite these reservations, this estimation performed on the basis of AGDREF data permits describing the flows of foreigners from non-EU countries required to apply for a residence permit from 1998 up to quite recently (Albis and Boubtane, 2015). 


\section{Debates and policies focused on immigration}

7 This flaw in migratory statistics on departures from French territory has perhaps directed attention focused debate only on arrivals in France, rather than to an analysis of departures. In their criticism of the fact that departures are not taken into account in migratory statistics, Legoux and Orain (2014) signalled that this situation led to overestimating the contribution of migration to the growth of the French population. These imperfect statistics may explain the low number of studies on departures, returns, emigration and emigrants, thereby biasing our vision of migrations. In a note on the situation of French nationals living outside France, Gonzales (2014) indicated that the very terms emigrants and emigration are very rarely used in public debates; the terms "expatriation" or "French nationals settled abroad" are generally preferred. This lexical choice highlights the difficulty of thinking of France as a country of emigration. The number of studies devoted to the immigration, reception and living conditions of immigrants and their descendants is impressive. On the contrary, works focusing on the emigration of French citizens are rare. Public debates and policies almost exclusively centre on immigration policy and on the conditions under which immigrants are received in France ${ }^{2}$. There is nothing or very little on departures, apart from the policy of returns (assisted) and expulsions of foreign populations. This prism leads to omitting emigration as such and to focusing attention more on the impacts of immigration.

8 The fact that, historically, France has one of the oldest traditions of immigration in Europe may explain the emphasis given to immigrants only. Since the $19^{\text {th }}$ century, migrants from the whole of Europe came here to settle (Belgium, Great Britain, Germany, Switzerland, etc.), then from Poland, Spain and Italy following the First World War, then after 1945, from Portugal, North Africa and more recently from SubSaharan Africa and Asia (Noiriel, 2016; Lessault and Beauchemin, 2009). Furthermore, as underlined by Héran (2016), France was not, contrary to its neighbours (Great Britain, Ireland, Germany, Italy), the source of considerable migratory flows to the New World, due to formerly more moderate demographic growth. It is generally considered to be a country of immigration rather than one of emigration.

The new method of estimating migratory flows between France and other countries developed by the INSEE specifically permits refocusing attention to obtain a more global view of migrations. It remains an estimation, and by definition improvable, and we do not ignore the risk of error it entails. Several methodological works (Arbel and Costemalle, 2016) have sought to compare the quality of AGDREF data and annual census surveys ("EAR"). These two sources have led to diverging estimations of flows. The census survey data tend to underestimate arrivals from abroad in comparison to AGDREF data which are limited by the fact that they cover only certain categories of migrant (Arbel et Costemalle, 2016). The purpose of this article is not to present these technical considerations on the quality of each of these sources. In our opinion, these two sources of data permit estimating flows that can be used in synergy to obtain global knowledge of migratory flows between France and abroad. However, the main interest of the method used by the INSEE is that for the first time it presents not only statistics on entries into France, but also on departures. Another advantage is that these statistics do not focus only on flows of foreigners but also take into account the movements of French nationals. 


\title{
The estimation of migratory flows between France and abroad
}

\author{
Migratory flows and balances: elements of definition
}

Inflows of migrants in France take into account all the people coming to settle or resettle in France, whether they are foreign or not. Thus flows of entries and arrivals of immigrants should not be confounded, since not everyone entering France should be considered a migrant. For example, tourists on short stays are not included in these flows. As said above, the international statistical definition of migration refers to a stay or an intention to stay in France exceeding twelve months. The INSEE's statistics on migratory flows are sent to Eurostat and have been deemed in compliance with regulation no. 862/2007 of the European Parliament and Council relating to community statistics on migration and international protection ${ }^{3}$. Hence they allow international comparisons.

11 Flows of departures from the territory include any person who has left France during the year, whether they are French and have made the decision to live abroad or foreign nationals returning to their country of origin, for example, after ending their studies or in the framework of occupational mobility. These departures can also include those of foreigners to another country of emigration.

It is known that the increase of the French population results from natural growth (births - deaths) and the migratory balance. The latter is in fact estimated indirectly, from the difference between, on the one hand, the evolution of the total population as measured between successive censuses and, on the other hand, the natural balance (births - deaths) of the year calculated using personal data. Since the population census data from 1 January 2006 to 1 January 2013 are known (cf. Box 1), we have the migratory balance for the years 2006 to 2012, while for the following years, the estimations of the population are provisional. They are performed by updating the population on 1 January 2013 indicated by the latest available census, thanks on the one hand to the natural balance and on the other to an estimation of the migratory balance. The migratory balance for 2013 is estimated provisionally using the last three definitive balances (2010, 2011 and 2012). This balance was reported for 2014, also provisionally. These migratory balances will be revised in January 2017, when the population census of 2014 is communicated.

We propose a study of flows of migratory flows between France and abroad for three categories of the population: people born in France, immigrants, i.e. foreign nationals born abroad, and French persons born abroad. This breakdown of the migratory balance for these three groups of people allows going beyond aggregated results where flows in the opposite direction according to the origin of individuals offset reach other.

Box 1: The renovated census of the population and the measurement of migratory flows

As early as 2004, the INSEE implemented a new method of measuring the population. Formerly carried out exhaustively about every ten years up to 1999 , the population census was replaced by annual census surveys (EAR). Municipalities with 10,000 inhabitants or more, in which live half the country's inhabitants, are 
henceforth subject to an annual survey of a sample of $8 \%$ of the population, dispersed over the entire municipality. After a period of five years, the entire territory of these municipalities is taken into account and the census results are calculated using a sample of $40 \%$ of their population made up in this way. For the other half of the population, residing in municipalities with fewer than 10,000 inhabitants, they are surveyed exhaustively every five years, and an annual estimation is performed by interpolation or extrapolation on the basis of the survey data. The scope of the EAR is defined by all the people residing in France for at least one year or, for new arrivals, those who intend to stay in France for at least one year.

In order to transmit the data within the periods determined by the new European Parliament regulation ${ }^{4}$ (data relating to year $\mathrm{N}$ must be sent to Eurostat no later than at the end of year $\mathrm{N}+1$ ) and ensure consistency with the demographic balance, the INSEE has decided to use the EAR to measure flows of entries. Furthermore, as from the EAR of 2011, the change of questionnaire provided the opportunity to revise the method of estimating entries to send new data to Eurostat at the end of 2013. Indeed, since 2011, for the purposes of European harmonisation, the question relating to the previous place of residence no longer concerns the situation five years before, but one year before. Thus, previous presence abroad is identified more precisely. Indeed, over a period of five years the same person could migrate several times for more than one year between France and abroad.

On 1 January 2015, 66.3 million people lived in France ${ }^{5}$. Between the beginning of 2006 and the beginning of 2015, the population increased by 3.2 million $^{6}$. The migratory balance, $+510,000$ people over the entire period, amounted to $16 \%$ of this increase. Over the period, this migratory balance therefore reached $+57,000$ a year on average. This is the result of a negative migratory balance for people born in France $(-107,000)$ and positive for immigrants $(+150,000)$ and people of French nationality born abroad $(+14,000)$. The migratory balance of immigrants was globally stable over the period 2006-2014, whereas that of people born in France showed a net increase, from - 60000 to -120000 over the period. These two contrary trends for French nationals and immigrants do not appear in the global migratory balance of the whole population. But taken alone, these two migratory balances give only partial information on migratory flows between France and other countries. It therefore appears advisable to break them down between flows of entries and departures to better understand the evolutions. 
Graph 1: Migratory balances between France and other countries by category of the population (period 2006-2014)

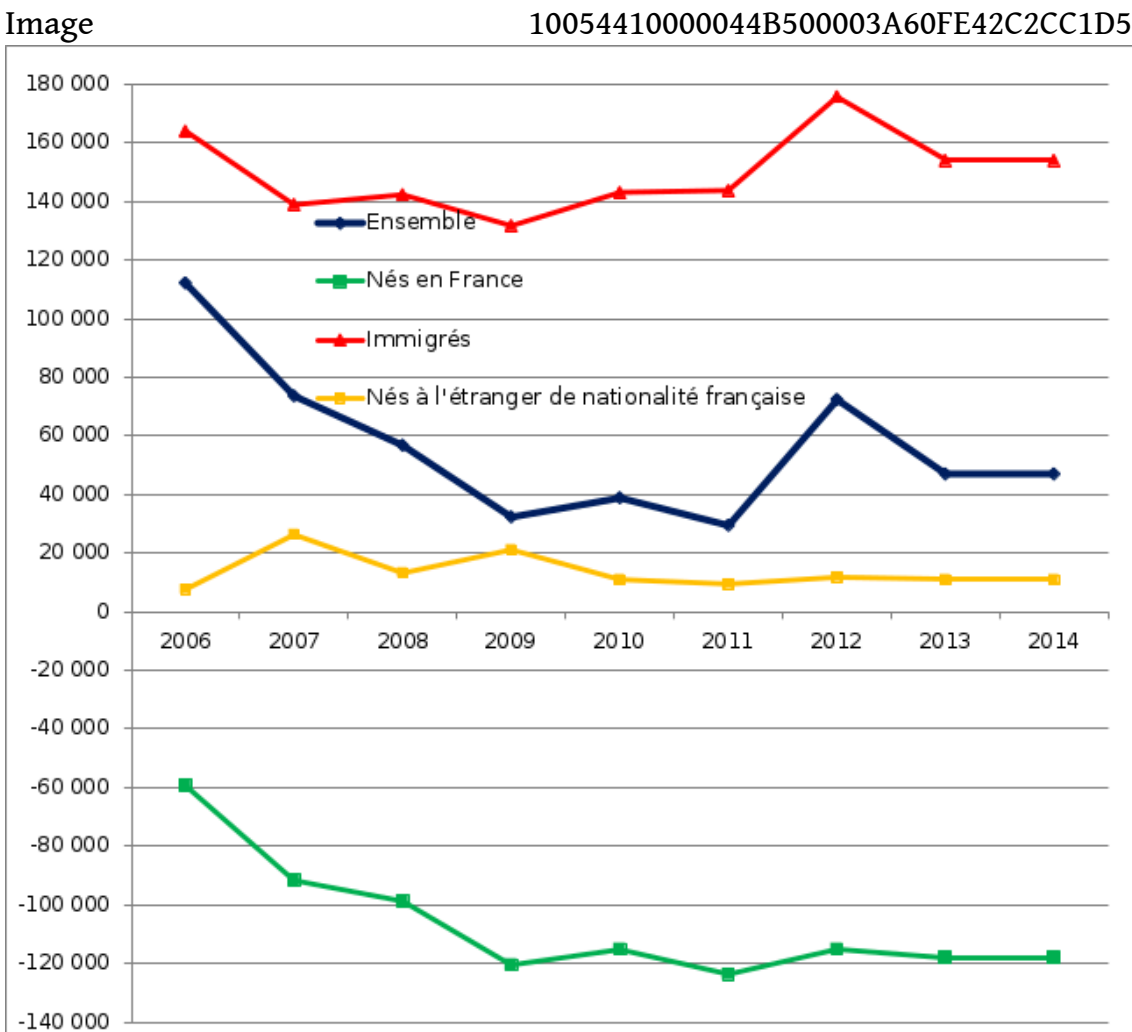

Source: INSEE, France (including Mayotte as from 2014)

\section{Estimating flows of entries}

The method of estimating entries in France is based on variables relating to the year of entry, information required only from persons born abroad, and the previous place of residence, available for all the persons surveyed. An analysis of the consistency of the data filled in by one person (year of arrival, previous residence, date of settling), to distinguish the responses effectively supplied from those imputed, led to privileging the response on the year of arrival when available in relation to the variable on the previous place of residence. When the information on the year of arrival was missing (the case of people born in France or people born abroad and who did not answer this question), it was the previous place of residence that allowed determining whether a person was a migrant or not (Brutel, 2014b). Since the question on the previous place of residence was changed in 2011, the entries measured on the basis of the EAR of 2005 to 2010 had to be re-estimated.

Box 2: Method of calculating entry flows

The entries of year $\mathrm{N}$ are estimated as follows:

* For the years $\mathrm{N} \geq 2010$ the following are counted as entries in the annual census survey $\mathrm{N}+1$ :

- people who have declared year $\mathrm{N}$ as their year of arrival; 
- people residing abroad on 1 January $\mathrm{N}$ (except if they gave year $\mathrm{N}+1$ as their year of arrival);

- children born abroad in $\mathrm{N}$ (except if they arrived in $\mathrm{N}+1$ ).

* These criteria are transposed to the EAR 2005 to 2010 by adapting them, taking into account the fact that the question on previous residence refers to the situation on 1 January N-4 and not to 1 January $\mathrm{N}$.

* For the years $\mathrm{N}$ between 2004 and 2009, the following are counted as entries using the annual census survey $\mathrm{N}+1$ :

- people declaring year $\mathrm{N}$ as their year of arrival;

- children born abroad in year $\mathrm{N}$ (except if they arrived in $\mathrm{N}+1$ ).

- To determine the entries of other persons of more than one year, i.e. those for which there is not enough information on the year of arrival in France (not applicable for children born in France or no answer for those born abroad) or for those whose year of arrival in France precedes N-4, the method chosen consists in estimating the number of entries of year $\mathrm{N}$, by applying to each of the populations concerned (born in France or born abroad) the rates of entry detailed by gender and age observed with the EAR of 2011. These rates are defined, for each category of the population, as the ratio between the number of people counted in the entries with the EAR of 2011 (i.e. the people declaring that they live abroad on 1 January N) and the total number of the category. This solution ensures sufficiently consistent global levels between the old and new EAR, without it being possible however to ensure that there is no break in the series (the methods and data used are different).

\section{Estimating entry flows}

16 As mentioned above, there is no statistical source ${ }^{7}$ capable of estimating the number of people that leave France for a period of at least twelve months. Therefore departures are estimated by deduction, from the difference between the migratory balance and the entries. They therefore include the uncertainties on the migratory balance, and those linked to the estimation of entries. They are nonetheless low in comparison to the evolutions observed over a period of seven years. The evolution of the mobility of people born in France observed using this method is consistent with that obtained from the OECD database. Several countries use their own statistical sources to estimate the flows of entries and/or departures of people born in France.

\section{Flows of entries and departures by category of the population}

The global number of entries in France can be broken down according to the sociodemographic variables available in the annual census surveys, for example the country of birth, gender, age and the level of education, making it possible to describe the people concerned.

In 2014, 340,000 people arrived in France of which 234,000 were immigrants, i.e. nearly $70 \%$ of all the entries. The other entries correspond to returns of persons born in France $(84,000)$ and the arrival of persons born French abroad $(22,000)$. On the 
contrary, 293,000 people left France. 80,000 immigrants returned abroad, i.e. more than $27 \%$ of the departures from France. These departures were mainly foreign students leaving France at the end of their studies, persons who had come to the end of a period of employment of several years, or who had returned to their home country on retirement. 202,000 people born in France left the territory in 2014. They represented nearly $70 \%$ of the total number of departures. There were few returns abroad of people born in France $(11,000)$. Thus two main migratory movements can be observed (the arrival of an immigrant population in France and the departures of French nationals abroad) and two movements induced by the previous ones (the return of immigrants to their countries of origin or a new departure to another country following a migration in France, and the returns of French nationals having previously migrated abroad).

Given these geographic movements, the migratory balances of immigrants $(+154,000)$ and persons born French abroad $(+11,000)$ are both positive, with the entries exceeding the departures. On the contrary, that of persons born in France is negative $(-118,000)$; it substantially offsets the positive migratory balances of immigrants and persons born French abroad, therefore leading to a low migratory balance for the entire population $(+47,000)$. Globally, the entries and departures from the territory each represented $0.5 \%$ of the total population in 2014, i.e. a level that has been stable since 2006, and not very different from the arrivals of persons born abroad: $0.4 \%$ of the entire population and lower than the average of OECD countries (0.6\%).

Graph 2: Rate of entries of persons born abroad in the main OECD countries

Image

100CB8EC0000635900003D6FDC118CF61911849B.emf

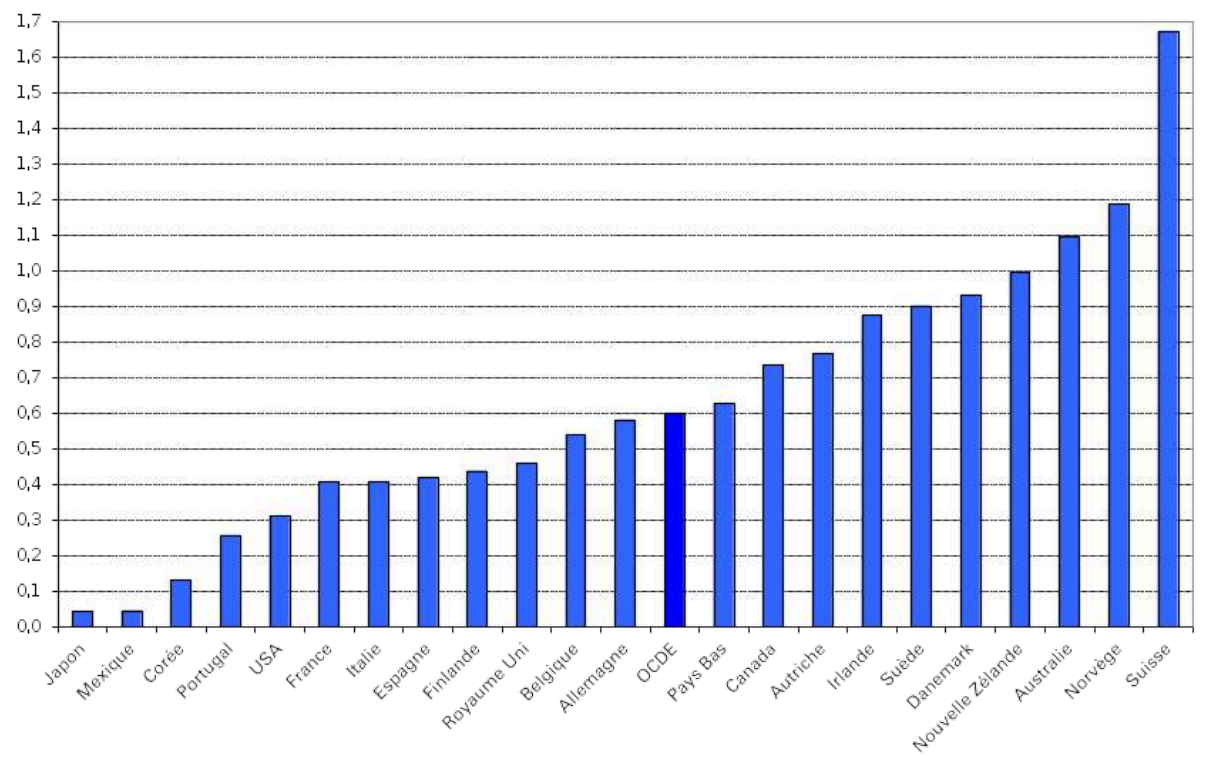

Source: OECD.

The rate of entry of immigrants is logically higher than the global rate: $4 \%$ of immigrants residing in France in 2014 arrived in 2013 and 1.3\% left the territory. The population born in France is obviously far more mobile, with a rate of departure of $0.3 \%$ and a rate of return to France of $0.2 \%$. The size effect between the immigrant population and that of persons born in France nonetheless limits the comparison of these rates. 
Graph 3: Evolution of the number of entries in France

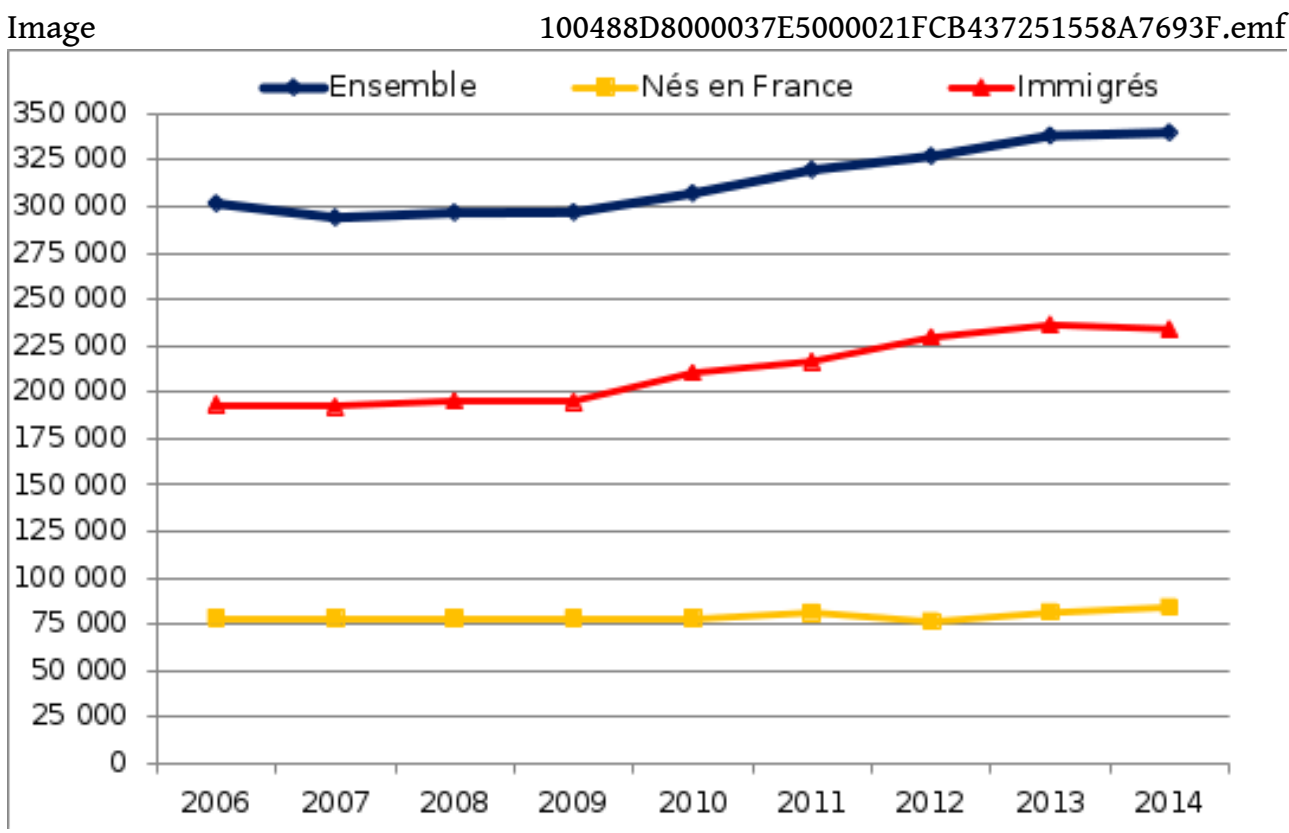

Source: INSEE, France.

Graph 4: Evolution of the number of departures from France

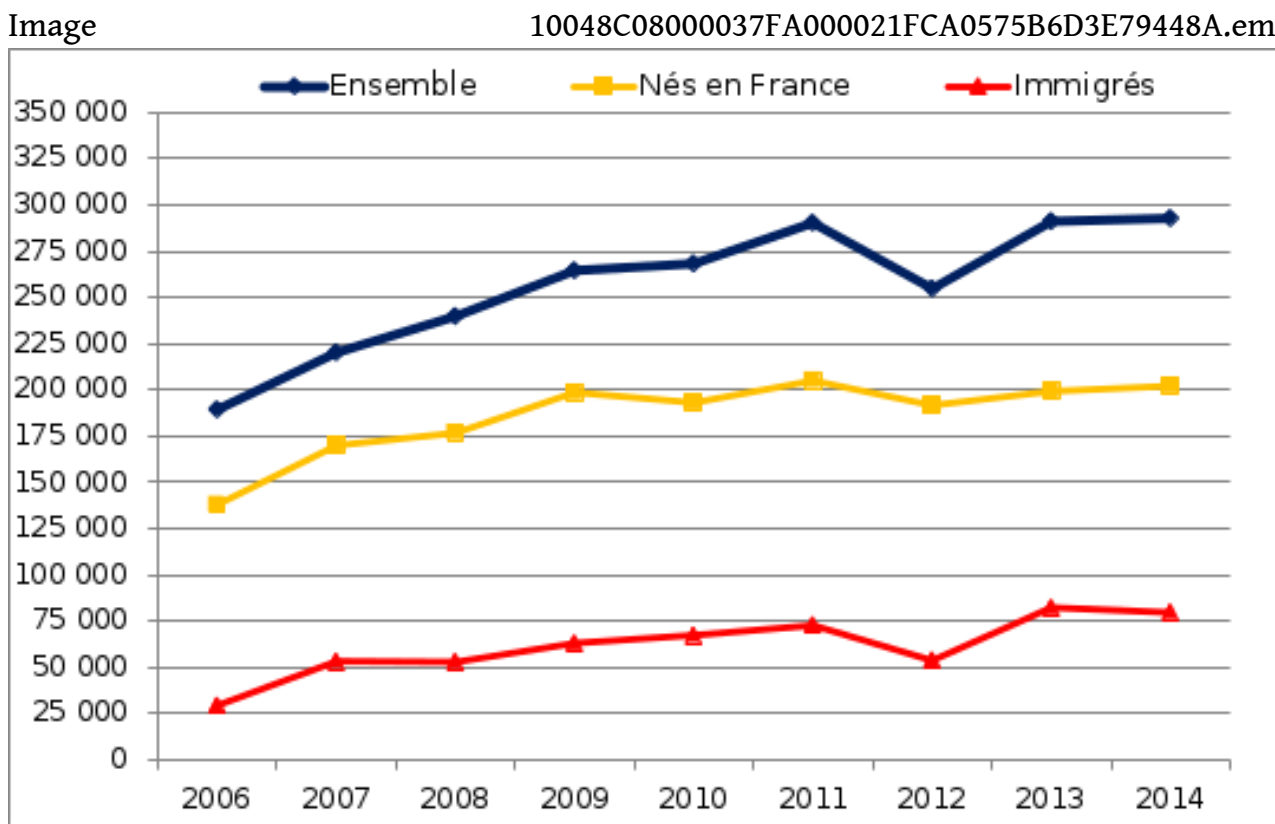

Source: INSEE, France.

21 From 2006 to 2014, the total migratory balance of France fell from $+112,000$ to $+47,000$, as the number of departures had increased faster than the number of entries. This observation mainly stems from the increase in the number of persons born in France leaving to go abroad. Indeed, over the period, the number of departures rose by $5 \%$ a year on average. In 2014, more than 200,000 people born in France left the territory, i.e. 64,000 more than in 2006. In parallel with this intensification of departures, the returns 
of persons born in France remained stable, despite the observation of a slight rise in the number of returns in 2014. Consequently, the negative migratory balance of persons born in France was strengthened over the period (from -60,000 to -120,000). Alongside persons born in France, there were about ten departures abroad for four returns. Regarding the immigrant population, this ratio reaches ten entries into France for a little fewer than three departures abroad (return to the country of origin or departure to another country of emigration). Thus, two movements in opposite directions offset each other in the migratory balance of the entire population.

Most of the departures abroad of persons born in France concern young adults. They leave at between eighteen and twenty-nine years of age, thus the ages of studies and starting work. One out of ten departures involves a young person younger than eighteen ${ }^{8}$. The persons born in France and who return after a stay abroad are logically older: half of them are between eighteen and twenty-nine and a third between thirty and forty-four years old. Between 2006 and 2014, the structure by age of the mobility of persons born in France has changed little; those between thirty and fifty-four years old are nonetheless slightly more numerous in leaving while those over fifty five are slightly less numerous in leaving.

Graph 5: Profile by age of return of persons born in France (in \%)

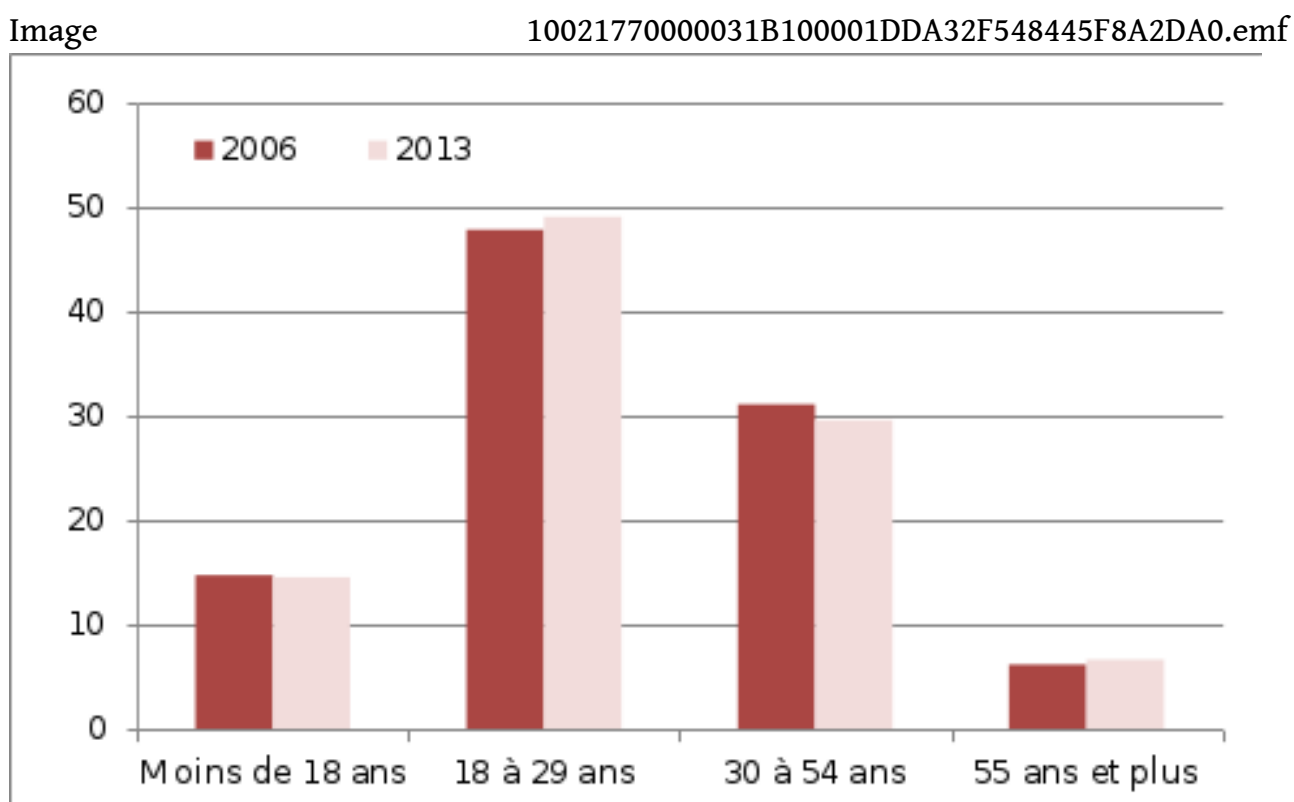

Source: INSEE, France.

Between 2006 and 2014, the departures of immigrants also increased $(+51,000)$. Thus, 80,000 people left France in 2014, i.e. three times more than in 2006. At the same time, their entries increased by only 41,000 people. Therefore the migratory balance of immigrants fell slightly: it was estimated at $+154,000$ in 2014 versus $+164,000$ in 2006 . The increase in short-term professional mobility, especially intra-European, may explain this observation.

The increase in migratory flows is not specific to France (OECD, 2015). Between 2006 and 2013, the number of immigrants in all twenty eight countries of the European Union increased by 208,000 and the number of departures increased by 802,000 . In 
2013, the migratory balance of the entire European Union therefore rose by $+575,000$ (3.4 million entries and 2.8 million departures), i.e. 594,000 fewer than in 2006. The situation differs according to country. For example, the migratory balance of Germany rose strongly; conversely, that of Spain became negative. These trends point to an intensification of departures from France. They invite us to go beyond aggregated data where the flows of populations in opposite directions are offset.

\section{Conclusion: changing the way in which migrations are viewed}

France has for a long time failed to comply with international recommendations on statistics on migratory flows with foreign countries. Although the flows of foreigners entering France were known, nothing was known of the flows of departures. Worse still, we know nothing of the annual migratory flows of French nationals. This new method of estimating migratory flows between France and foreign countries developed by the INSEE permits solving these shortcomings. It is an annual estimation method that can be improved and used in synergy with other existing statistical sources. For the first time it provides a global view of migratory flows and their trends. It therefore offers political and institutional decision-makers, civil society, the world of research and the general public, essential information on all the entries into and departures out of France. The data resulting from these estimations provides fuel for scientific and political debate and should contribute to adjusting the attention hitherto given almost exclusively to immigration into France and widen our scope to take in other flows, the stakes of which are equally important for the country's demographic and societal dynamics.

The first results obtained from this method show that although France is indeed a country of immigration, it is also one of emigration, with not inconsiderable flows of departures to other countries that largely offset arrivals. What is more, recent trends show that these departures from France by French nationals and foreigners are increasing. Lastly, these results demonstrate the need to see the permanency of migrants settling in France after their arrival in relative terms and they point more to the migratory circulation of populations between France and foreign countries.

\section{BIBLIOGRAPHY}

Albis Hippolyte (d') et Boubtane Ekrame (2016) De la difficulté d'estimer les flux migratoires, Association française de science économique, [en ligne] consulté le 24/07/2016. URL: http:// www.blog-afse.fr/content/de-la-difficulté-d'estimer-les-flux-migratoires

Albis Hippolyte (d') et Boubtane Ekrame (2015) Caractérisation des flux migratoires en France à partir des statistiques de délivrance de titres de séjour (1998-2013), Population, 70 (3), pp. 487-523 
Arbel Julyan et Costemalle Vianney (2016) Estimation des flux d'immigration: réconciliation de deux sources par une approche bayésienne, Économie et statistique, 483-484-485, pp. 121-149.

Bellamy Vanessa et Beaumel Catherine (2015) Bilan démographique 2014. Des décès moins nombreux, Insee Première, 1532, 4 p.

Brutel Chantal (2015a) L'analyse des flux migratoires entre la France et l'étranger entre 2006 et 2013, Insee Analyses, 22, 4 p.

Brutel Chantal (2015b) Population française, étrangère et immigrée en France depuis 2006, Insee Focus, $38,4 \mathrm{p}$.

Brutel Chantal (2014a) Les immigrés récemment arrivés en France. Une immigration de plus en plus européenne, Insee Première, 1524, 4 p.

Brutel Chantal (2014b) Estimer les flux d'entrée sur le territoire à partir des enquêtes annuelles de recensement, Document de travail Insee, F1403, 24 p.

Cornuau Frédérique et Dunezat Xavier (2008) L'immigration en France: concepts, contours et politiques, Espace populations sociétés, 2, [en ligne] consulté le 04/10/2016. URL: http:// eps.revues.org/3330 ; DOI: 10.4000/eps.3330

Gonzales Julien (2014) Trop d'émigrés ? Regards sur ceux qui partent de France, Fondapol, 52 p., [en ligne] consulté le 15/10/2016. URL: http://www.fondapol.org/etude/julien-gonzalez-tropemigres-regards-sur-ceux-qui-partent-de-france/

Héran François (2016) Parlons immigration en 30 questions, Paris, La Documentation française, 104 p. Legoux Luc et Orain Renaud (2014) Une étrange absence. La faible prise en compte des sorties dans les statistiques migratoires, e-Migrinter, 12, (en ligne). URL: https://e-migrinter.revues.org/ 389

Lessault David et Beauchemin Cris (2009) Les migrations d'Afrique subsaharienne en Europe: un essor encore limité, Population \& Sociétés, 452, 4 p.

Mazuy Magali, Barbieri Magali, Breton Didier et Albis Hippolyte (d') (2015) L'évolution démographique récente de la France et ses tendances depuis 70 ans, Population, 70 (3), pp. 417-486.

Mazuy Magali, Prioux France et Barbieri Magali (2011) L'évolution démographique récente en France. Quelques différences entre les Départements d'outre-mer et la France métropolitaine, Population, 66 (3-4), pp. 503-554.

Noiriel Gérard (2016) Le Creuset français. Histoire de l'immigration (XIXe-XXe siècle), Paris, Points, $447 \mathrm{p}$.

OCDE (2015) Perspectives des migrations internationales en 2015, Paris, OCDE, 383 p.

ONU (1998) Recommandations en matière de statistiques des migrations internationales - Révision 1, New York, Publication des Nations Unies ST/ESA/STAT/SER.M/58/Rev.1.

Riandey Benoit (2007) Le nouveau système d'information de l'assurance maladie en France permettrait-il une estimation des flux d'émigration ?, Aidelf, 12, pp. 93-107.

Thierry Xavier (2008a) Migrations: le défi statistique européen, Futuribles, 343, pp. 61-77.

Thierry Xavier (2008b) Les migrations internationales en Europe: vers l'harmonisation des statistiques, Population \& Sociétés, 442, 4 p.

Thierry Xavier (2001) Les entrées d'étrangers en France de 1994 à 1999, Population, 3, pp. 423-450. 


\section{NOTES}

1. http://eur-lex.europa.eu/legal-content/fr/TXT/?uri=CELEX\%3A32007R0862

2. For several years, politicians have started to speak of the expatriation of French nationals.

3. http://eur-lex.europa.eu/legal-content/fr/TXT/?uri=CELEX\%3A32007R0862

4. http://eur-lex.europa.eu/LexUriServ/LexUriServ.do?uri=OJ:L:2007:199:0023:0029:FR:PDF

5. 64.2 million in metropolitan France and 2.1 million in the five overseas departments.

6. From 1 January 2014, the population of Mayotte, estimated at 220,000 inhabitants, has been incorporated in the French population.

7. The permanent demographic sampling (PDS), a panel of individuals, is being analysed to measure flows of departures from the territory. The new version of the PDS now comprises data from tax sources.

8. These may be children accompanying their migrating parents.

\section{ABSTRACTS}

The measure of migratory flows has always been a difficult and awkward task. During the last decades, the knowledge about immigration flows, and specially emigration flows, has been incomplete, making difficult any international comparison. A new methodology for estimating flows between France and other countries, designed by Insee and presented in this article, offers a global vision of migrations, insofar as, for the first time departures from French territory are taken into account (not only of foreigners, but also of nationals). The first results for the period 2006-2014 show that, even if France remains an immigration country, people also leave it, so it is also an emigration territory.

La mesure des flux migratoires a toujours été complexe et délicate. Au cours des dernières décennies, la connaissance des flux d'immigration et surtout d'émigration est restée incomplète rendant difficiles les comparaisons internationales. La nouvelle méthode d'estimation des flux migratoires entre la France et l'étranger, mise au point par l'Insee et présentée dans cet article, nous offre une vision globale des migrations, en ce qu'elle permet de traiter, pour la première fois, de la question des sorties du territoire français, de la part d'étrangers, mais aussi de nationaux. Les premiers résultats de la période récente (2006-2014) indiquent que si la France reste un pays d'immigration, elle est aussi un pays de départ et donc un territoire d'émigration.

La medición de los flujos migratorios ha sido siempre compleja y delicada. En las últimas décadas, los trabajos sobre los flujos de inmigrantes y, sobretodo, de emigrantes, han sido muy limitados, dificultando así toda posibilidad de realizar estudios comparativos a nivel internacional. El nuevo método de cálculo de flujos migratorios entre Francia y otros países, actualizado por el Insee y presentado en este artículo, nos ofrece una visión global de las migraciones, permitiendo analizar por primera vez no solo la salida de extranjeros del territorio francés, sino también la de los propios nacionales. Los primeros resultados relativos al periodo 2006-2014 indican que, aunque Francia sigue siendo un país de inmigración, es también un territorio desde el cual «se producen» salidas, y por tanto, es un país de emigración. 
INDEX

Keywords: flows, immigration, emigration, methodology, departure, arrivals, return, French, foreigners, migratory circulation

Palabras claves: flujos, inmigración, emigración, metodología, partida, entrada, retorno, francés, extranjeros, circulación migratoria

Mots-clés: flux, immigration, émigration, méthodologie, départ, entrée, retour, Français, étrangers, circulation migratoire

\section{AUTHORS}

\section{FRANCK TEMPORAL}

Sociodemographer, Associate Professor, Université Paris Descartes, CEPED, 45 rue des Saints-

Pères, 75006 Paris ; franck.temporal@ceped.org

\section{CHANTAL BRUTEL}

Administrator of the INSEE in charge of the "immigration and statistics and studies unit", INSEE, 18 boulevard Adolphe Pinard, 75675 Paris Cedex 14; chantal.brutel@insee.fr 